\title{
IDENTITIES AND CONCEPTIONS OF BORDER AREA POPULATIONS IN EAST-CENTRAL AND SOUTH-EAST EUROPE - THEMATIC ASPECTS AND QUESTIONS OF AN ACTUAL RESEARCH FIELD
}

\author{
Wilfried HELLER \\ Institute of Geography, University of Potsdam, Germany
}

\begin{abstract}
This article will be structured as follows: Firstly, it will be described what is to be understood by the term 'identity'. After that, this article will explore the significance of the topic 'identities of population' regarding the political, social, economic and cultural developments in the border areas of East-Central and South-East Europe. Because identities are not essentially but constructed phenomena, the next chapter will deal with the role of conceptions of the border area populations for the building of identity. The then following remarks on categories of border areas shall suggest that a great variety of border areas needs to be considered if one is occupied with the subject of this article. From these explanations the article's relation to application will be derived, and groups of questions as well as detailed questions will be developed.
\end{abstract}

Key Words: identities, regionalism, centralism, European integration process, globalization, border areas, East-Central and South-East Europe

\section{Considerations about the term 'identity'}

"We Europeans still do not know much about each other!" complained the Luxemburgian prime minister Jean-Claude Juncker addressing graduates of the 'Europe sciences studies' at the Humboldt University of Berlin on 21st October 2009. The article which will be presented in the following should enlarge the stock of knowledge about European countries. This knowledge is necessary for a careful European integration process. This article shall be destinated to one of those subjects which have not being studied enough until now despite their great significance for Europe.

Identity has been a popular word of the Zeitgeist for more than two decades already. Since the so-called psycho-wave of the 1980s, the needs and wishes of individuals and groups are seen as a reaction to the dominant interest for social structures and systems in the 1960s and 1970s. The identity of groups will be related to families, relationship and personal connections as well as to linguistic, religious and other cultural common grounds, but also to local, regional and national bonds, that is, to ties to areas and states. 'Identity' is to be understood as a feeling or a certainty of belonging to a certain group or area or to be one with this group or area. If this feeling or certainty is related to an area or region it is referred to spatial or regional identity, respectively.

Social and cultural sciences consider identity - defined as the consciousness or the feeling of belonging to a social network or a locality or an area and the feeling of oneness with these dominantly as result of individual or collective action and no longer as a primordial category. Identity is changeable in principle (see for example Aschauer 1996 and 2000a; Brunnbauer 
2002).

After the political change in former socialist countries more attention is paid again - as in the socialist period - to collective identities of ethnic and national character as a reaction to the socialist period or because of the lack of other opportunities of identification (see for example Binder/Niedermüller/Kaschuba 2001).

'Space related identification' is a process during the course of which an individual or a group acquires and shows affiliation to a space or a region. 'Space' or 'region' is understood as follows: 1 , an administrative or a physically delimitable section of the surface of the earth; 2 , a space of action without such kinds of borders, that is, a space which is determined by the ranges of activities of the people (space of action); 3, a space characterised by the perception of the people (space of perception); this space can vary concerning its size, shape and features (see for example Heller/Aschauer 2004).

\section{Identities in East-Central and South-East Europe as objects of research and their significance for the process of European integration}

The population of Europe is characterised by a great variety of identities on different spatial levels, including the national, regional and local levels. This is true especially for East-Central and South-East Europe because on the one hand several cultural areas intersect in this part of the continent, namely, 1, Western Christianity with the European big powers of the Habsburg monarchy and Prussia, 2, Eastern orthodox Christianity with the Byzantine empire and later with Russia as an eastern European hegemonic power, and 3, Islam with the Ottoman empire. On the other hand, East-Central and South-East Europe are marked by a very many recent changes of state borders and by a complicated pattern of migrations. So a lot of territories with specific spatial structures and population have arisen. The political borders of these territories are often of very different duration (see for example the map of Gilfillan 1924). However, the persistence of spatial structures makes it possible to see former cultural and state affiliations even today where state borders have not existed for a long time. Knowledge about these structures is important for the political decision-makers in Europe, if the EU enlargement and consolidation process is to be successful. Border areas are an important category of analysis. The application of this category of analysis can contribute to a better understanding of the diversity of Europe.

Besides the historical facts of the pre-socialist period as factors which have an influence on the character of the identities of the border areas, the following factors also need to be considered: 1 , the socialist period, 2, the period of transition and in this respect the so-called second modernization, 3 , the influences of globalisation and the regional and local protagonists who react to these influences in different manners.

The regional and local protagonists maintain that globalisation does not cause a homogenisation of the world society, which was sometimes feared at the beginning of the globalization debate. However, instead of this homogenisation, a differentiated spatial pattern with a mixture of a lot of political, social, economic and cultural characteristics has been created. In other words, a so-called hybridisation of the societies on different spatial scales is taking place. The expression of the economic space of this hybridisation has been compared with the pattern of the fur of a leopard (see for example Krätke 1996). Each of the different parts of this spatial pattern is constructed and imagined in a specific manner. Here it will be proposed that empirical studies of this subject should consider how these constructions and conceptions are made. It is intended that the individuals and groups will be studied with the aim 
of seeing the manner in which they are locally and regionally anchored on the one side, and what kinds of globalised behaviour they show on the other side. An example could be the activation of local and regional potentials of economic and of business-relations. At the same time, new kinds of technology are used and new patterns of consumption are adopted. So, new spaces of action are created. They can overlap one another. These spaces will be studied with respect to their significance for the building of identities within the population. With the help of a comparison of the space-related identities found in the border areas of East-Central and SouthEast Europe, new formations of spatial identity shall be worked out.

What matters in the European integration process is to respect the different identities and at the same time, to strengthen the common ground as basis for the transnational community of the EU. A precondition for this task is the knowledge and respect for identity because only by considering actual identities can the different members of the EU perceive, understand and accept each other individually. So, identity means the delimitation of other people and affiliation with a larger entity as well as maintaining self-reliance (see for example Glaser 2001).

Especially in border areas, the question of a space-related identity is important to ask, because political borders do not necessarily mean cultural, social and economic borders, even in cases when they are permeable. As a consequence of border-crossings, the following kinds of areas are established: areas of exchange and areas where characteristics of the territories on both sides of the border overlap and are combined. So, the population can have a specific identity, that is, an identity specific for this border area. Nevertheless, it can also be characterised by two or more identities. These border areas can be considered as areas of interference, that is as areas which are marked by overlaps and coincidences of cultural phenomena and activities of different groups of population and of reciprocal relations between these groups. So, heterogenous societies with overlapping identities are established. One can call this feature interferentiality. Interferentiality is not restricted to border areas although it exists more abundantly in such areas.

In addition, there is the question of whether a border area has significance for the building of a certain spatial identity at all, because it is possible that all facts which seem to be characteristic for border areas are only variants of processes controlled from outside of the areas, that is, by processes of market economy or political processes. Examples of these processes are constructions of national identity made by the state central administrations or the introduction of a certain opinion on the history of the border and of the nations and ethnic groups who live there. So, the significance of a nearby border to identity building could be small compared to the effects of the construction of the general national identity. Lastly, theoretic knowledge of the significance of the proximity of a border does not exist to this day.

It seems to the author that there is hardly any scientific publication which explicitely addresses the subject of this article. The amount of existing studies on borders is huge, and the studies are full of sporadic and vague cross-reference to the category of border population. However, in spite of their different perspectives, more or less all of them proceed from the subject 'border' and not from the subject 'population of border areas'. Recent studies (as of Agnew 2007, 2008) mainly deal with the question of which factors have to be envisaged as being crucial for border making. It is from this particular perspective that Agnew analyzes the hitherto existing border studies. His analysis is not based on a typology of border studies (as, for example, Kolossov 2005) but rather on the work of Sahlin (1989) which deals with the production of the boundaries of national territories. Agnew refers to Sahlin by saying that he marked a position "that has been widely influential in border studies and that is often seen as representing a radical departure from 'old-style' studies based on center-periphery and top-down 
understandings of how borders come about and are maintained." (Agnew 2007, p. 399). In spite of Agnew's overt concern with the overall effects of border making, he implicitely casts a view on identities of border populations as being secondary to or derived from political borders. This article, however, proposes to go beyond these derivative notions of identity and border population: It strives for relating these categories to border building as being part of reflexive, recursive processes. In doing so, it intends to avoid preconceptions which define border building as kind of an "independent" variable in terms of nomothetical explanations. Instead, it looks for open interrelations between categories which have to be reconstructed from social practice rather than be derived from abstract schemes.

Until now, the scientific and political interest explicitely concerning the EU border areas is concentrated on their social, economic and ecologically harmless development as well as on cross-border cooperation (see for example Roch/Scott/Ziegler 1998 and conference of Akademie für Raumforschung und Landesplanung/Leibniz-Forum für Raumwissenschaften on 2nd November 2009 in Berlin on "Cross-border interaction - Cross-border governance?"). For obvious reasons, this subject is interesting because border areas act as links for European cohesion. They play an important role in the European integration process which aims at a harmonic and balanced economic and social development of the member states and parts of their areas. However, the EU is also interested in the border areas of their neighbouring countries. Developments without tensions in these areas and states are useful for a good neighbourhood and therefore, for economy and society in general.

\section{Conceptions of border area populations - their significance for the building of identity}

The history and therefore the conception of the history that a population has, that is, the cultural memory which a population has, is important for the building of identity. With regard to this subject the following questions are interesting: What kinds of conceptions do exist about the history of the border area, about the population on both sides of the border and about other populations? A concrete example of history concerns the conceptions which the border area population has about the consequences of the political, social and economic developments of the EU for the border areas: In what manner are the border area inhabitants influenced by these developments? Do they feel that they are target groups of EU politics? Therefore, do they build a special identity different from the dominant national identity of the population of the states? Do they represent special population groups within a "Europe of Regions" which work and can be used as enzymes to spark the consolidation of the relations of the EU states among themselves and for the success of the future enlargement process?

However, the picture of the border area populations about their space of living and activities does not depend only on the politics of the EU but also essentially on the politics of the nation states. So, an important role is played by the question: What degree of independence do the political centres of the states grant to the provinces and to different regional units, especially to those regional units on the periphery. Do the central administrations allow the production of a regional self-confidence? Or do they brake and hinder the building of a border area related identity because they are afraid of too strong regionalisms and therefore, of a weakening of the national states? On the other hand: Do the central administrations support the regional movements, perhaps because they suggest that as a consequence of a stronger space-related identity the border population commits itself more to its region, and so the space-related identity can work as a development potential what is ultimately useful for the country as a whole? Is a strong identity of the border area population favourable for the structuring of crossborder relations, perhaps especially in those cases where a population which is ethnically similar or identical lives on the other side of the border? 


\section{Categories of border areas}

Empirical studies can be made with examples ordered by areas along state borders and along cultural borders. Each of these two categories can be divided into two groups. The first category can be divided based on areas along the internal and external borders of the EU. The second category can be divided with regard to areas of cultural interference inside of EU states and in the bordering neighbour countries. The reasons for the proposal of this structure are the following ones:

Border areas as categories of analysis became more important in East-Central and South-East Europe because of the enlargement process of the EU (see for example Sterbling 2009). Some border areas of certain countries have been reshaped by this process into double border areas, so to speak, that is, into border areas which became not only border areas of states but also of the EU. The EU tries to compensate or at least to reduce this disadvantage of the location, for example, by spending money from regional structure and cohesion funds. By these means, the national programmes for the support of the problem regions are promoted. On the other hand, the border areas of other states have been liberated from the character of double border areas because they are not longer located along the external border of the EU as a consequence of the enlargement process. A detailed examination would be required to see whether these areas, which are now only "simple" border areas are disadvantaged by their peripheral location inside the territory of the country, or whether they have an advantage because of the neighbourhood to an EU member country. As a consequence, the state border has become permeable. The closer cooperation with a neighbour country could have positive effects on the social and economic development on both sides of this new internal border of the EU.

Another new category of border areas is represented by the areas of those countries which are adjacent to the EU. The effects of the EU enlargement on these states are conflicting: On the one side, their western borders became more impermeable because of lack of access of the western neighbouring countries to the EU; on the other side, they can profit from the neighbourhood politics of the EU, which are concentrated on political, economic and social stability.

Probably, the European integration process can be predominantly evaluated positively concerning its political, economic and social effects on border areas, apart from the effects on areas of those countries which are located along the eastern border of the EU. However, this would have to be examined. On the contrary, the influences of the political and economic centres of the countries are to be seen as ambivalent. On the one hand, the centres are interested in a comprehensive development of the country, of the peripheral areas as well, while on the other hand, the centres can be afraid of the fact that the regions could become too independent and therefore separatist. Even the state systems of East-Central and South-East Europe are traditionally regarded as centralist, also because of the fact that in the socialist period centralism had been strengthened.

\section{The connection of this article's subject to application}

Border areas of East-Central and South-East Europe are an important subject of research because by studying the developments of these areas much can be learnt about the development of the EU in general. However, it is an open question whether the EU enlargements have influenced the opinion of the population of the border areas in such a manner that new identities have arisen. This suggests that identities are not to be conceived as 
essentialistic and so not as unchangeable, but in fact, identities change together with political, social and economic development, and even new identities can be created (see for example Norton 2007, Weigl 2004).

The knowledge about these processes contributes to a better understanding of the consequences of the EU enlargements. This knowledge can be used in the debate on future enlargements of the EU, and even in cases where the effects of the general, national constructions of identity are regarded as stronger than the effects of the production of local and regional identity. Concerning this fact, whether the identities which arise in the new border areas can work as so-called soft location factors needs to be examined. It is well-known that the quality of such factors is ascribed to the local and regional identity in multiple ways (see for example JOHN 1998, ASCHAUER 2000 b). On the one hand, it is supposed that a population identifying itself with its locality and its region is more engaged with their region or locality, develops more ideas for it and works more for it. In this sense, a strong space-related identity, for example, can be regarded as a kind of endogenous development potential. On the other hand, local and regional identity is propagated as attraction factors in the field of city and regional marketing, for example, for enterprises which intend to settle there or for tourism.

\section{Groups of questions and detailed questions to be considered by empirical studies: a proposal}

Corresponding to the exposition made above, a proposal for research questions shall be presented in the following. Empirical studies could consider the following groups of questions and detailed questions:

(1) Self-image of the population of border areas:

- What kinds of identities of the population can be found in border areas?

- How do the border area inhabitants perceive themselves? What features of quality do they ascribe themselves?

- $\quad$ Do multiple identities respectively mixtures of identities exist, too?

- When have the identities been established?

- What structural conditions - political, economic, cultural, social and demographic - did exist at the time of the building of the identities?

- Who (state institutions and protagonists, interest groups etc) did cause the creation of identity and who contributed to it? What kinds of motives and aims did they have?

- What conceptions of the history (cultural memory) one can see in these self-ascribed identities?।

- What effects do the self-image - that is, the conception and assumption of the border area population about itself - have on the other people, that is, the population outside the border area and on the inhabitants of the area on the other side of the border? Can they produce tensions?

(2) Image of other people about the border area population:

- What conception and assumption of the identities of border area inhabitants exist outside the border area? In other words, what kinds of identities are ascribed to the border area inhabitants?

- Who are the representatives (activists and multipliers) of these ascriptions?

- What kinds of motives and aims do they have?

- What kinds of conception of the history one can see in these identities ascribed 
Identities and Conceptions of Border Area Populations in East-Central and South-East Europe - Thematic Aspects and Questions of an Actual Research Field

from outside?

- What effects does the image of other people - that is the conception and assumption of people living outside the border area of the border area population - have on the border area population on both sides of the border? Does it have a hostile potential?

(3) The significance of centre and periphery in multi-ethnic and multi-national states:

- What significance do the relation between centre and periphery in multi-ethnic and multi-national states have for the building and shaping of the self-image and other image of the border area populations?

(4) Significance of centralism, European integration process and globalisation:

- What role do state centralism, the European integration process and globalisation processes play in the concerned countries with regard to the building and shaping of self-image, of the image of other people and possibly of the concepts of an enemy?

(5) The application of this article's subject:

- What aspects of the self-image and of the image of other people and what historic experiences as well as actual political developments, concepts and measures can contribute to an understanding across the border and to a reduction of tensions between centralism and regionalism inside of one and the same state if they exist?

This list of questions which is not complete, touches a subject where is still a big gap in research. Therefore, finding answers to these questions should be one of the subjects of empirical studies focused on East-Central and South-East Europe. In doing so, additional knowledge considering the subject 'Europe - unity in variety?' can be acquired. This knowledge can be useful for the future EU integration politics.

\section{References}

AGNEW, J. (2007), No Borders, No Nations: Making Greece in Macedonia, in: Annals of the Association of American Geographers, 97 (2): 398-422.

AGNEW, J. (2008), Borders on the mind: re-framing border thinking, in: Ethics \& Global Politics, Vol. 1, No. 4: 175-191.

ASCHAUER, W. (1996), Identität als Begriff und Realität, in: HELLER W., (Ed.), Identität - Regionalbewusstsein - Ethnizität. Potsdam: 1-16 (= Praxis Kultur- und Sozialgeographie, H. 13)

ASCHAUER, W. (2000 a), Verschränkungen und Unverträglichkeiten von regionaler und ethnischer Identität im Landesteil Schleswig, in: Zeitschrift für Kultur - und Bildungswissenschaft. Flensburger Universitätszeitschrift, 10: 89-98.

ASCHAUER, W. (2000 b), Zwischen Analyse und Politik. Zum Anwendungsbezug regionalwissenschaftlicher Forschung, in: Informationen der Raumentwicklung, H. 9/10: 589598.

BINDER, B., NIEDERMÜLLER, P., KASCHUBA, W. (2001), Inszenierungen des Nationalen - einige einleitende Bemerkungen, in: BINDER, B., NIEDERMÜLLER, P., KASCHUBA, W. (Ed.), Inszenierungen des Nationalen. Geschichte, Kultur und die Polititk der Identitäten am Ende des 20. Jahrhunderts. Köln, Weimar, Wien: 7-15, (= alltag \& kultur, vol. 7).

BRUNNBAUER, U. (2002), Einleitung zu BRUNNBAUER Ulf (Ed.), Umstrittene Identitäten. Ethnizität und Nationalität in Südosteuropa. Frankfurt am Main: 11-29.

GILFILLAN, S. C. (1924), European Political Boundaries, in: Political Science Quarterly, vol. 39, Academy of Political Science, Lancaster, Pennsylvania, Columbia University, New 
York: $458-484$

GLASER, H. (2001), Kultur und Identitäten, in: Aus Politik und Zeitgeschichte. Beilage zur Wochenzeitung Das Parlament, 7. Dezember, B 50/2001: 3-5.

HELLER, W., ASCHAUER, W. (2004), Regionen als Instrumente der Kooperation und Integration, in: Revue des études sud-est européenes. Académie Roumaine. Institut d'études sud-est européenes. Tome XLII, no. 1-4, Bucureşti: 271-292.

JOHN, R. (1998), Regionale Identität: Strategie und Diskurs im Raum BerlinBrandenburg, in: BISS public, H. 25, 8. Jg., 1. Halbjahresband: 71-91.

KOLOSSOV, V. (2005), Border Studies: Changing perspectives and theoretical approaches, in: Geopolitics, 10: 606-632.

KRÄTKE, St. (1996), Probleme und Perspektiven der deutsch-polnischen Grenzregion, in: SCHULTZ, H., NOTHNAGLE, A. (Ed.): Grenze der Hoffnung. Geschichte und Perspektiven der Grenzregion an der Oder. Potsdam:162-203 (= Frankfurter Studien zur Grenzregion, Bd. 1).

NORTON, C. (2007), Nationalism and the Re-Invention of Early-Modern Identities in the Ottoman-Habsburg Boderlands, in: ROTH, Klaus/BRUNNBAUER, Ulf (Ed.): Region, Regional Identity and Regionalism in Southeastern Europe. Berlin: 79-101 (= Ethnologica Balkanica, 11). ROCH, I., SCOTT, J., ZIEGLER, A. (1998), Umweltgerechte Entwicklung von Grenzregionen durch kooperatives Handeln, Dresden (=IÖR-Schriften, 24).

SAHLINS, P. (1989), Boundaries: the making of France and Spain in the Pyrenees, Berkeley, CA, University of California Press.

STERBLING, A. (2009), Europäische Dynamik und periphere Räume - soziale Aspekte, in: HELLER, W., SALLANZ, J. (Ed.): Die Dobrudscha. Ein neuer Grenzraum der Europäischen Union: Sozioökonomische, ethnische, politisch-geographische und ökologische Probleme. München, Berlin: 73-87 (= Südosteuropa-Studien, 76).

WEIGL, M. (2004), Die Bedeutung der Geschichte für die Konstituierung regionaler Identität im bayerisch-böhmischen Grenzraum. Paper, München, 5 th February.

ZAJAK, P. (2009), Interferenzialität als mitteleuropäisches Raumparadigma, in: CSÁKY, M., LEITGEB, C. (Ed.): Kommunikation Gedächtnis Raum. Kulturwissenschaften nach dem „Spatial Turn“, Bielefeld: 133-147.

Initial submission, September 5, 2010

Revised submission, December 15, 2010

Final acceptance, April 28, 2011

Correspondence: Institute of Geography, University of Potsdam, Karl-Liebknecht-Straße 24/25, Haus 9, Zimmer 2.12, Potsdam (Golm), Germany, 14476.

E-mail: heller@uni-potsdam.de 